Enlightenment and Catholicism in Europe 
Burson.indb 2 


\title{
Enlightenment Catholicism
}

\author{
Europe
}

A Transnational History

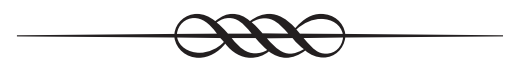

edited by
Jeffrey D. Burson and Ulrich L. Lehner

University of Notre Dame Press

Notre Dame, Indiana 
Copyright (? 2013 by University of Notre Dame Press

Notre Dame, Indiana 46556

www.undpress.nd.edu

All Rights Reserved

Manufactured in the United States of America

Chapter 19 is an abridged and revised version of Mark Goldie, "Alexander Geddes at the Limits of the Catholic Enlightenment," Historical Journal 53, no. 1 (2010): 61-86.

(c) Cambridge University Press, reproduced with permission.

Library of Congress Cataloging-in-Publication Data

$\infty$ The paper in this book meets the guidelines for permanence and durability of the Committee on Production Guidelines for Book Longevity of the

Council on Library Resources. 


\section{Contents}

Introduction: Catholicism and Enlightenment, Past, Present, and Future JEFFREY D. BURSON

\section{PART 1}

Catholic Enlightenment and the Papacy

1 Pope Benedict XIV (1740-1758): The Ambivalent Enlightener MARIO ROSA

\section{PART 2}

Catholicism and the Siècle des Lumières in France and Savoy

2 Nicolas-Sylvestre Bergier (1718-1790): An Enlightened Anti-Philosophe

JEFFREY D. BURSON

3 Giacinto Sigismondo Cardinal Gerdil (1718-1802): Enlightenment as Cultural and Religious Achievement DRIES VANYSACKER

4 Adrien Lamourette (1742-1794): The Unconventional 109 Revolutionary and Reformer CAROLINE CHOPELIN-BLANC 
5 Joseph de Maistre (1753-1821): Heir of the Enlightenment, 127 Enemy of Revolutions, and Spiritual Progressivist CAROLINA ARMENTEROS

6 Hugues-Félicité Robert de Lamennais (1782-1854):

Lost Sheep of the Religious Enlightenment

CAROLINA ARMENTEROS

\section{PART 3}

Catholic Enlightenment in the Holy Roman Empire

$7 \quad$ Benedict Stattler (1728-1797): The Reinvention of

Catholic Theology with the Help of Wolffian Metaphysics ULRICH L. LEHNER

8 Beda Mayr (1742-1794): Ecumenism and Dialogue with Modern Thought

ULRICH L. LEHNER

$$
\text { PART } 4
$$

Catholicism, Enlightenment, and Habsburg Europe

9 Franz Stephan Rautenstrauch (1734-1785): Church

Reform for the Sake of the State

THOMAS WALLNIG

10 Johann Pezzl (1756-1823): Enlightenment in the Satirical Mode

RITCHIE ROBERTSON

\section{PART 5 \\ Varieties of Italian Catholic Enlightenment}

11 Lodovico Antonio Muratori (1672-1750): Enlightenment in a Tridentine Mode

PAOLA VISMARA 
12 Antonio Genovesi (1713-1769): Reform through

Commerce and Renewed Natural Law

NICCOLÒ GUASTI

13 Maria Gaetana Agnesi (1718-1799): Science and Mysticism 291 MASSIMO MAZZOTTI

$$
\text { PART } 6
$$

Catholicism, Enlightenment, and the Iberian States

14 Benito Jerónimo Feijoo y Montenegro (1676-1764):

Benedictine and Skeptic Enlightener

FRANCISCO SÁNCHEZ-BLANCO

15 Josep Climent i Avinent (1706-1781): Enlightened

Catholic, Civic Humanist, Seditionist

ANDREA J. SMIDT

\section{PART 7}

Transnational Trajectories: The Intersection of Irish, French, Italian, and Habsburg Developments

16 Ruggiero Boscovich (1711-1787): Jesuit Science in an

Enlightenment Context

JONATHAN A. WRIGHT

17 Luke Joseph Hooke (1714-1796): Theological Tolerance in an Apologetic Mold

THOMAS O'CONNOR

$$
\text { PART } 8
$$

Catholicism in Protestant Territorial-Dynastic States: Scottish and English Enlightenment Variations

18 Andrew Michael Ramsay (1686-1743): Catholic Freethinking and Enlightened Mysticism GABRIEL GLICKMAN 
19 Alexander Geddes (1737-1802): Biblical Criticism, 413 Ecclesiastical Democracy, and Jacobinism MARK GOLDIE

PART 9

The Polish Catholic Enlightenment

20 Stanisław Konarski (1700-1772): A Polish Machiavelli? JERZY LUKOWSKI

21 Hugo Kołłątaj (1750-1812): The Revolutionary Priest ANNA ŁYSIAK-ŁĄTKOWSKA

List of Contributors

Index 